\title{
Comparison of two Radiometers in the Validation of the Irradiance Emitted in the Light Curing Apparatus of the Faculty of Medical Sciences and Health of Juiz De Fora /SUPREMA
}

\author{
Diogo de Azevedo Miranda ${ }^{a}$, Andressa dos Santos Souzai ${ }^{b}$, Marianna Lessa de Souza ${ }^{b}$, \\ Paula Bedeschi Roman da Costa \\ ${ }^{a}$ Adjunct Professor of Faculty of Medical Sciences and Health of Juiz De Fora \\ ${ }^{\mathrm{b}}$ Student, Dental of Faculty of Medical Sciences and Health of Juiz De Fora \\ Department of Dentistry, Faculty of Medical Sciences and Health of Juiz De Fora, Brazil
}

\section{Address for correspondence:}

Dr. Diogo de Azevedo Miranda,

Rua Sampaio 330/602, Granbery, Juiz de Fora, Minas Gerais 36010-360, Brazil

\begin{abstract}
Introduction: For better clinical execution, the performance of LED light curing agents is gaining space in dentistry. For a better efficiency of the photopolymerizers, the intensity of the light through the radiometers must be validated with the constant periodical maintenance so that the emission of light is within the standards of irradiance established by the manufacturers. Objective: To compare the irradiance measured by two Ecel RD-7 and SDI radiometers, respectively. Method: 8 Bluephase-based photopolymerizers were used when the batteries were fully charged. For each apparatus were measured three readings and then averaged. Results: The exploratory analysis of the data indicated homoscedasticity, that is, there is a significant difference between the variances of the two devices. Conclusion: The Ecel RD-7 radiometer with rechargeable battery presented better results than the SDI radiometer.
\end{abstract}

Keywords: Photopolymerization; Light; Irradiation.

\section{Introduction}

Currently in dentistry restorative materials have peculiar characteristics such as restoring form, function and, above all, aesthetics to the dental element. Due to the technological advancement of companies of dental materials, it is observed that the composite resin is widely used in aesthetic restorations. For better application of these materials, the different brands of light curing devices are highlighted in the emission of radiance according to the variation of their intensities. Therefore, for clinical practice, light-curing devices are essential in the work environment of dental surgeons. ${ }^{[1,2]}$

Light curing devices are instruments that emit high intensity blue light, being found in two types on the market: rigid fiber optic and flexible fiber2. The mechanism of these devices starts from the ideal emitted wavelength, being able to vary from 410 to $500 \mathrm{~nm} 3$. The photopolymerization process is related to camphorquinone which is characterized as a photoinitiator frequently found in most photopolymerizable dental materials. ${ }^{[3]}$ When exposed to light, in the presence of initiators such as amines, the formation of free radicals occurs which, in turn, initiate the polymerization process by the conversion of monomers into polymers. ${ }^{[3]}$

For better clinical performance, halogen lamp light curing is being replaced by LEDs. LED is the acronym in English for Light Emitting Diode. It is composed of a blue light which is determined by the chemical combination of two different semiconductors that establishes the wavelength of emission, characterizing more closely as the spectral distribution. The result of this composition is a lower energy consumption and low heat production. It is concluded that the main advantage for this substitution is the production of visible light through quantum mechanical effects instead of the heating of metallic filaments. ${ }^{[3]}$

The loss of light intensity is evident in several studies and in clinical practice. The procedures associated with high chances of clinical failure are directly related to the polymer formed by a particular light source. The factors responsible for the success of a restoration in composite resin can be classified in sufficient emission of light intensity, correct wavelength emitted, adequate exposure time and type of tip. However, factors such as type, color 


\section{International Journal of Innovative Research in Medical Science (IJIRMS) \\ Volume 03 Issue 11 Nov 2018, ISSN: 2455-8737, Imp. Factor - 4.102 \\ Available online at $-\underline{w w w . i j i r m s . i n}$}

and opacity of the composite resin, thickness of the increment, composite temperature, distance from the tip of the light to the surface of the restorative material and the time after radiation influence the polymerization and degree of conversion of the composite resins. ${ }^{[4,5,6]}$

At present there are specific radiometers for each type of light curing device, whether it comes from halogen light or LED light. ${ }^{[7,8]}$ Some light-curing devices have radiometers attached at their base that verify the maximum intensity the device emits, but not exactly its value. This facilitates daily dental procedures for dental surgeons as they instantly reproduce if the device is in perfect condition for use. ${ }^{[3,4]}$

Thus, the radiance of photopolymerizers generated by the photoactivation apparatus are very important parameters to achieve maximum conversion of monomers into polymers. ${ }^{[9,10]}$ The purpose of this study were evaluated the ability of the radiometer to measure the intensity of light waves at the point of exit of the light-curing of the photopolymerizer in LED.

\section{Methods}

\subsection{Experimental Design}

The present study was of experimental quantitative character, whose non-probabilistic sample was composed of 10 photopolymerizers of the Bluephase brand, with only 8 being in a legitimate state of operation. The criterion used for evaluation was its complete charge, battery quality and light tip quality.

The factors under study were third-generation light-curing devices at one level $(\mathrm{n}=10)$ - Bluephase LED device with dark tip. The response variable was the values of irradiance emitted after the use of a radiometer, in two levels: brand Ecel RD-7 and mark SDI.

\subsection{Reading of Apparatus Irradiance}

Before measuring with the radiometer, each light-curing device of the brand Bluephase tested was fired once for 20 seconds in High mode. Then the light-curing tip was placed in contact with the photosensitive surface of the radiometer, so that the tip was centered on the photosensitive cell and perpendicular to it. At this time, the photopolymerizer was activated and, after 20 seconds of activation, the observed intensity was recorded.

For reading, the Ecel RD-7 and SDI Radiometers were used, which were calibrated every 4 readings (figures 2 and 3). After removing the devices from the loader bases, the light bulb of each device was placed directly on the radiometer sensor and, after 20 seconds, with a flashing light, the devices emitted the value of the irradiance generated for each photopolymerizer.

\section{Results}

\subsection{Statistical analysis}

After the data collection, the irradiance values of each device were tabulated and, afterwards, a mean of the values found for the devices tested was made. The mean results of the model of the apparatus in question are shown in grafic 1. The exploratory analysis of the data indicated homoscedasticity, that is, that there is no significant difference between the variances of the two devices.
Thus, Student's t-test was applied for homogeneous variances for the comparison between the devices, regarding radiance values. The analyzes were performed in the $\mathrm{R} *$ program considering the level of significance of $5 \%$.

*R Core Team (2017). R: A language and environment for statistical computing. R Foundation for Statistical Computing, Vienna, Austria.URL https://www.R-project.org/

\subsection{Irradiance}

Table 1: Mean and standard deviation of radiance depending on the device

\begin{tabular}{|l|c|c|}
\hline & \multicolumn{2}{|c|}{ Appliance } \\
\hline & Universal SDI & Radiometer Ecel RD-7 \\
\hline Mean & 1200,70 & 1436,60 \\
\hline Standart & 112,56 & 169,18 \\
\hline
\end{tabular}

$p=0,0017$

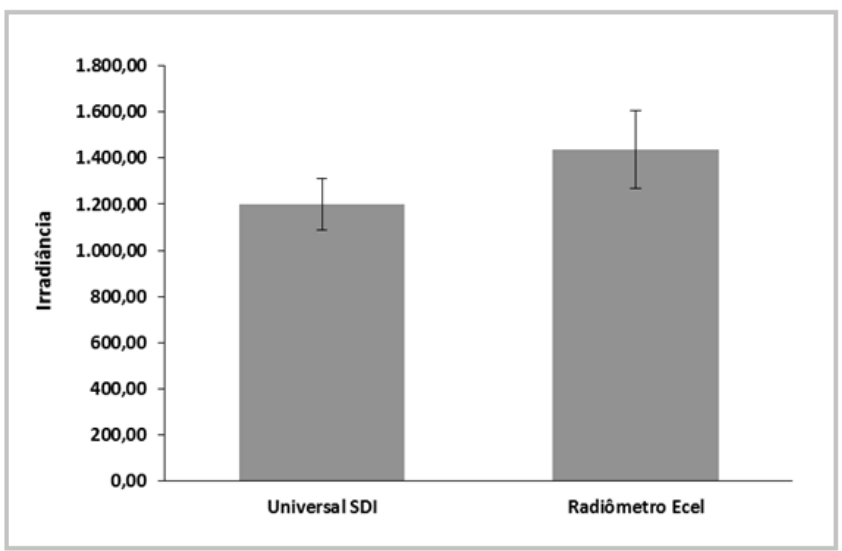

Graphic 1: Mean and standard deviation of irradiance according to the apparatus.

\section{Discussion}

Dentistry gains strength through the use of restorative materials, which have a number of physical, chemical and biological requirements and the ability of these materials to restore shape, function and aesthetics to the dental element. ${ }^{[11,12]}$ According to the literature, a suitable polymerization should have a radiance of around $400 \mathrm{~mW} / \mathrm{cm}^{2}$ (milliwatts per square centimeter), with a time of 20s (seconds), with a minimum acceptable value of 300 $\mathrm{mW} / \mathrm{cm}^{2}{ }^{[13]}$

It is important to note that periodic maintenance should be carried out on the photopolymerizers every six months and that they should be replaced whenever necessary, according to the manufacturers. ${ }^{[3]}$ Success in a restorative procedure is directly related to the performance of the photopolymerizer. Periodic maintenance as well as part of the components, cleaning and light intensity are of paramount importance, since frequency and use are responsible for the wear of the appliance. ${ }^{[13]}$ Biosafety for the protection of patients and professionals is aimed at avoiding crossinfection, therefore, it is necessary to disinfect the photopolymerizers. ${ }^{[15]}$

Thus, to ensure that appliances perform their light intensity over time, it is critical that academics and clinicians be aware of the care to avoid problems caused by residual monomers. The aid of a 


\section{International Journal of Innovative Research in Medical Science (IJIRMS) Volume 03 Issue 11 Nov 2018, ISSN: 2455-8737, Imp. Factor - 4.102 Available online at $-\underline{w w w . i j i r m s . i n}$}

radiometer is essential to ensure adequate polymerization of composite resins. ${ }^{[12,13]}$

The quality of the battery of the photopolymerizers may be another factor that may lead to a difference in values. ${ }^{[16,17]}$ Even if a voltmeter was not used, the devices were tested from the moment they showed constant charged battery lights and consequently the acquisition time of these influenced the potential of the batteries used. ${ }^{[18,19]}$ It is important to note that the life time of a replaceable battery is approximately 1200 photopolymerizations with a duration of 10 seconds each, and may resemble a watch battery. ${ }^{[20,21,22]}$

The last factor that may interfere with the results is the measurement of the light point, since the closer it is to the tip of the photopolymerizer, the less light is dissipated and thus, the more reliable is the result obtained by the radiometer. ${ }^{[18,23]}$

Regarding light intensity values, it is recommended that devices with an intensity of less than $200 \mathrm{~mW} / \mathrm{cm}^{2}$ be routed for maintenance, as the composite resin will not be adequately polymerized. Devices with light intensity between 201 and 399 $\mathrm{mW} / \mathrm{cm}^{2}$ are acceptable, but require additional polymerization time. Light intensities of $300 \mathrm{~mW} / \mathrm{cm}^{2}$ are sufficient when the appropriate exposure time is used. And devices with light intensity greater than $400 \mathrm{~mW} / \mathrm{cm}^{2}$ can be used with the exposure time of 20 seconds for increments of $2 \mathrm{~mm}$ of composite resin 1 .

\section{Conclusion}

From the results found in this study we can conclude that:

- $\quad$ Light curing devices used in the Dentistry Clinic of the Faculty of Medical Sciences and Health of Juiz de Fora / SUPREMA are suitable for dental use.

- Even if they are suitable for use, it is recommended that the apparatus be periodically maintained.

- The Ecel RD-7 radiometer with rechargeable battery presented better results than the SDI radiometer.

\section{References}

[1] Ribeiro RAO, Lima FFC, Lima IM, Nascimento ABL, Teixeira HM. Avaliação da intensidade de luz e da manutenção dos aparelhos fotopolimerizadores utilizados em Clínicas Odontológicas da cidade do Recife - PE. Revista de Odontologia da UNESP 2016; 45(6): 351355.

Disponível em:www.scielo.br/pdf/rounesp/v45n6/1807-2577rounesp-1807-257706916.pdf

[2] Pereira SK, Pascotto RC. Avaliação dos aparelhos fotopolimerizadores utilizados em Clínicas Odontológicas. J BrasDentEstet 2003; 2(5): 2935.Disponível em: https://www.dtscience.com/wpcontent/uploads/2015/10/Avaliacao-dos-Aparelhos-

Fotopolimerizadores-Utilizados-em-ClinicasOdontologicas21.pdf

[3] Marson FC, Mattos R, Sensi LG. Avaliação das condições de uso dos fotopolimerizadores. Revista Dentísticaonline 2010; 9(19): 15-20.Disponível em: www.ufsm.br/dentisticaonline/0903.pdf
[4] (Conceição EMet al., 2010). Dentística: Saúde e Estética. 2nd Ed. Porto Alegre: Artmed: 2007; 11: 201-210.

[5] Junior AEW, Siqueira DF, Scanavini MA, Kanashiro LK. Avaliação da potência de fotopolimerizadores à LED utilizados em consultórios. Ortodontia SPO 2009; 42(2): 95-100.Disponível em: http://www.ortociencia.com.br/Artigo/Index/1028

[6] (Baldi RL et al., 2005). Intensidade de luz de aparelhos fotopolimerizadores utilizados no curso de Odontologia da Universidade Estadual de Ponta Grossa. UEPG CiBiol Saúde. 2005 Mar; 11(1): 39-46.Disponível em: http://www.revistas2.uepg.br/index.php/biologica/article/ download/408/411

[7] Miranda DA, Catelan A, 2018. Living Polymerization Techniques And Their Utility in Material Synthesis. Annals Off Clinical Case Reports - Dentistry 2018. Disponível em: www.anncaserep.com/pdfs_folder/accrv3-id1494.pdf

[8] Chain, MC. Unidades Fotopolimerizadoras de Luz Visível. In: Baratieri, L.N. et al. Estética, restaurações adesivas diretas em dentes anteriores fraturados. São Paulo: Quintessence Editora Ltda. 1995: 13377.Disponível em: https://issuu.com/guanabarakoogan/docs/amostrasdepagi nas-baratieri

[9] Blazzio MD, Guimarães C, Assunção MCA. Descobrindo seufotopolimerizador. [online] Acesso em: 02/03/2005 Disponível na internet:http://www.ibemol.com.br/ciodf2001/352.asp. 2001.

[10] Silva KA, Pepe IM, Filardi VL, 2014. Construção de um radiômetro para construção de LEDs. Universidade Federal da Bahia, 2014.Disponível em: https://blog.ufba.br/pgif/files/2016/05/D146-IFUFBA.pdf

[11] Kreidler MAM, Lima DM, Rastelli ANS, Andrade MF. Avaliação da intensidade de luz dos aparelhos fotopolimerizadores. J BrasClinOdontolIntegr 2004; 8:249-253.Disponível em: http://www.periodicoseletronicos.ufma.br/index.php/rcis aude/article/download/971/2806

[12] (Mazur RF et al., 2004). Avaliação da qualidade dos aparelhos fotopolimerizadores da Clínica Odontológica da PUC-PR. Rev Ibero-americana Odontol Est Dent 2004; 3:160-168.Disponível em:http://www.revistas2.uepg.br/index.php/biologica/arti cle/download/408/411

[13] (Guiraldo RD et al., 2008). Influence of the light curing unit and thickness of residual dentin on generation of heat during composite photoactivation. J Oral Sci 2008; 50(2): 137-142.Disponível em: https://www.ncbi.nlm.nih.gov/pubmed/18587202

[14] (Miyazaki M., 1998). Evaluation of curing light used in private dental offices. OperativeDnetistry, 1998; v.23, n.3: 143-145.Disponível em: https://www.ncbi.nlm.nih.gov/pubmed/9573788

[15] Araujo RM, 1997. Efeito da intensidade de luz e irradiação de calor de fotopolimerizadores em função do tempo de uso. J BrasOdontolClin 1997; v.1, n.6: 5055.Disponível em: www.ufsm.br/dentisticaonline/0903.pdf 
[16] (Plasteret al., 2016). Efeito de diferentes fotopolimerizadores e meio de imersão na rugosidade e na cor de um compósito nanoparticulado. Rev Odontol UNESP, 2016; Sept-Oct; 45(5): 283-289.Disponível em: http://www.scielo.br/scielo.php?pid=S1807-

$25772016000500283 \&$ script=sci_abstract\&tlng=pt

[17] (Werlang JFG et al., 2013). Curing-light attenuation and depth of cure of composite resins.ArqOdontol, 2013; 49(1): 12-18.Disponível em: http://revodonto.bvsalud.org/scielo.php?script=sci_abstra ct\&pid=S1516-

09392013000100002\&lng=pt\&nrm=iss\&tlng=en

[18] (Beltrani FC et al., 2012). Avaliação da intensidade de luz e dos componentes dos aparelhos fotopolimerizadores da Clínica Odontológica da Universidade Estadual de Londrina. Revista Brasileira de Pesquisa em Saúde, 2012; 14(1): 5-11.Disponível em: www.periodicos.ufes.br/RBPS/article/download/3403/26 64

[19] (Godoy EP et al., 2007). Aparelhos fotopolimerizadores: elevação de temperatura produzida por meio da dentina e durante a polimerização da resina composta. RevClínPesqOdontol, 2007; 3(1): 11-20.Disponível em: http://www2.pucpr.br/reol/index.php/aor?dd1=1914\&dd $2=1497 \& d d 3=\& d d 99=p d f$

[20] (Correia IB et al., 2005). Avaliação da intensidade de luz, da manutenção e do método de utilização dos fotopolimerizadores utilizados nos consultórios da cidade de Caruaru - PE. RevOdontol UNESP, 2005; 34(3): 113118.Disponível em: http://drasimonecosta.com.br/wpcontent/uploads/2017/11/RUnesp2005v34n3.pdf

[21] Franco EB, Lopes LG. Conceitos atuais na polimerização de sistemas restauradores resinosos. Biodonto, 2003; 1(2): 10-59.Disponível em: http://www.scielo.br/scielo.php?script=sci_nlinks\&ref=0 00102\&pid=S1806-8324200900040001900008\&lng=pt

[22] (Gouvêa CVD et al., 2008). Avaliação dos aparelhos fotoativadores utilizados em odontologia. RGO, 2008; 56(4): 399-403.Disponível em: www.revistargo.com.br/include/getdoc.php?id=2910\&art icle $=630 \&$ mode $=$ pdf

[23] Freitas SAA, Costa JF, Bauer JRO. Avaliação da intensidade da luz dos aparelhos fotopolimerizadores utilizados em Clínicas Odontológicas de São Luís - MA. RevPesq Saúde, 2011; 12(2): 27-31.Disponível em: http://www.periodicoseletronicos.ufma.br/index.php/revi stahuufma/article/view/1048 